\section{Efektifitas Penyaluran Alokasi Dana Desa Pada Empat Desa Di Kabupaten Bojonegoro}

\section{Edy Suhartono ${ }^{1}$, Moh. Mustofa ${ }^{2}$}

${ }_{1}$ Program Studi Ekonomi Pembangunan, Universitas Bojonegoro, Indonesia

${ }_{2}$ Program Studi Ekonomi Pembangunan, Universitas Bojonegoro, Indonesia

*Korespondensi Penulis. E-mail: edysuhartono9119@gmail.com

\begin{abstract}
Abstrak
Pembangunan Daerah adalah bagian dari upaya pembangunan nasional yang memiliki dimana tujuannya adalah untuk meningkatkan kapasitas pemerintahan daerah dalam memberikan pelayanan yang optimal kepada masyarakat dan juga meningkatkan kemampuan daerah dalam pengelolaan sumberdaya ekonomi secara efisien dan efektif demi kemajuan daerah dan kesejahteraan masyarakat. Penelitian ini bertujuan untuk mencari bagaimana cara menilai efektifitas penyaluran Alokasi Dana Desa dari pemerintah Kabupaten Bojonegoro kepada pemerintah Desa yang meliputi perencanaan, pencairan dana, hingga pemanfaatan Alokasi Dana Desa di wilayah desa terkait, dan bagaimana cara menilai tingkat pertumbuhan pembangunan ekonomi antar desa dan disparitas (kesenjangan) pembangunan ekonomi antar wilayah di tingkat Desa dengan proksi pada tingkat Kecamatan. Data yang digunakan dalam penelitian ini adalah data sekunder yang berasal dari Badan Pusat Statistik (BPS) Kabupaten Bojonegoro, Data Alokasi Dana Desa dari Badan Pemberdayaan Masyarakat dan Pembangunan Desa (BPMPD) Kabupaten Bojonegoro, serta Data Monografi Desa, ada empat desa dari berbagai kecamatan di wilayah Bojonegoro. Hasil penelitian ini menunjukkan bahwa penyaluran Alokasi Dana Desa di empat desa tersebut belum mencapai efektifitas yang optimal. Hal tersebut dapat dilihat dari masih adanya kesenjangan (disparitas)
\end{abstract}

pembangunan ekonomi antar wilayah kecamatan dan cenderung memiliki nilai Indeks Williamson dari tahun 2014 hingga tahun 2018 mendekati nilai 1 (satu). Melalui analisa Klassn Typology dapat diketahui bahwa hasil dari pembangunan ekonomi selama tahun 2014 hingga tahun 2018, dari 28 kecamatan di Kabupaten Bojonegoro, Jawa Timur hanya beberapa daerah yang termasuk dalam kategori daerah cepat maju dan cepat tumbuh.

Kata Kunci: Alokasi Dana Desa, Pemberdayaan. Pembangunan

\section{EFFECTIVENESS OF VILLAGE FUND ALLOCATION DISTRIBUTION IN FOUR VILLAGES IN BOJONEGORO DISTRICT}

\begin{abstract}
Regional Development is part of the national development effort which has the purpose of which is to increase the capacity of regional government in providing optimal services to the community and also to increase the ability of the region to manage economic resources efficiently and effectively for the advancement of the region and the welfare of the community. This study aims to find out how to assess the effectiveness of the distribution of Village Fund Allocation from the Bojonegoro Regency government to the village government which includes planning, disbursement of funds, to the utilization of Village Fund Allocation in related village areas, and how to assess the level of economic development growth between villages and disparities (gap) economic development between regions at the village level with proxies at the district level. The data used in this study are secondary data from the Central Statistics Agency (BPS) of Bojonegoro Regency, Village Fund Allocation Data from the Community Empowerment and Village Development
\end{abstract}


Agency (BPMPD) of Bojonegoro Regency, and Village Monographs Data, there are four villages from various sub-districts in Bojonegoro region. The results of this study indicate that the distribution of Village Fund Allocation in the four villages has not yet reached optimal effectiveness. This can be seen from the still disparity (disparity) of economic development between sub-districts and tends to have a value of the Williamson Index from 2014 to 2018 close to 1 (one). Through the Klassn Typology analysis, it can be seen that the results of economic development during 2014 to 2018, from 28 subdistricts in Bojonegoro Regency, East Java, only a few regions were included in the fast-growing and fast-growing regions.

Keywords: Village Fund Allocation, Empowerment. Development

\section{A. PENDAHULUAN}

Sebelum pelaksanaan otonomi daerah, sistem kebijakan fiskal menyangkut transfer Pemerintah Pusat kepada Pemerintah Daerah, yaitu berbentuk Sumbangan Daerah Otonom (SDO) dan INPRES. Sedangkan saat ini menurut UU Nomor 25 tahun 1999, penerimaan daerah terdiri dari a) Pendapatan Asli Daerah (PAD) yang umumnya bersumber dari pajak daerah, retribusi dan laba BUMD; b) Dana Perimbangan yang terdiri atas Dana BPHTB, Dana Alokasi Umum (DAU) dan Dana Alokasi Khusus (DAK); c) Pinjaman Daerah.

Tujuan umum dari kebijakan otonomi daerah/desentralisasi ini adalah memberi peluang dan kesempatan bagi terwujudnya pemerintah yang baik dan bersih (clean and good governance) di daerah, yang berarti pelaksanaan tugas pemerintah daerah harus didasarkan atas prinsip efektif, efisien, terbuka, dan akuntabel.

Pemilihan lokasi penelitian di Bojonegoro berdasarkan beberapa hal, diantaranya adalah bahwa bentuk Desa di Bojonegoro masih terjaga hingga kini, walaupun jaman bergerak menjadi lebih modern. Kedua, Kabupaten Bojonegoro Propinsi Jawa Timur merupakan salah satu kabupaten yang memiliki tingkat pertumbuhan yang rendah dan juga ada beberapa desa yang masih termasuk ke dalam desa tertinggal di Indonesia.

Berlandaskan masalah di atas, agar pelaksanaan tugas yang diserahkan kepada desa dapat dilaksanakan secara efektif, efisien, terbuka, dan akuntabel, guna mencapai tujuan pemberdayaan pemerintah dan masyarakat desa, maka perlu dilakukan suatu upaya yang sistematis dalam menentukan urusan dan kewenangan yang diserahkan, berdasarkan prinsipprinsip pengaturan tentang desa dan mempertimbangkan faktorfaktor lainnya.

\section{B. TEORI (Literature Review)}

1. Kebijakan Otonomi Daerah (Desentralisasi)

Kebijakan otonomi daerah merupakan kebijakan yang menggeser dominasi penyelenggaraan kepemerintahan 
dari pusat ke daerah. Pergeseran ini memberikan peluangdan sekaligus tantangan bagi daerah untuk meningkatkan kualitas penyelenggaraan kepemerintahaanya serta meningkatkan akselerasi pembangunan didaerahnya. Tujuan umum dari kebijakan otonomi daerah/desentralisasi sebagaimana tersirat dalam Undang-Undang No.32 Tahun 2004 adalah a) memberi peluang dan kesempatan bagi terwujudnya pemerintah yang baik dan bersih (clean and good governance) di daerah dalam pelayanan publik, yang berarti tugas pemerintah daerah harus didasarkan atas prinsip efektif, efisien, terbuka, dan akuntabel; b) meningkatkan kesejahteraan rakyat dengan selalu memperhatikan kepentingan dan aspirasi yang tumbuh dalam masyarakat; c) menjamin keserasian hubungan antara daerah satu dengan daerah lainnya, artinya mampu membangun kerjasama antar daerah dengan daerah lainnya untuk meningkatkan kesejahteraan bersama dan mencegah ketimpangan antar daerah; d) menjamin hubungan yang serasi antara daerah dengan pemerintah, artinya harus mampu memelihara dan menjaga keutuhan wilayah Negara dan tetap tegaknya Negara Kesatuan Republik Indonesia dalam rangka mewujudkan tujuan Negara; e) meningkatkan daya saing daerah untuk mendukung ekonomi nasional

\section{Efektivitas Pengalokasian Dana Desa}

Menurut Nick Devas (1989) prinsip-prinsip dasar pengelolaan keuangan daerah yang mengalami perubahan paradigma seiring dengan pencanangan konsep "good governance" dalam penyelenggaraan pemerintahan, adalah a) Transparansi dimana adanya keterbukaan pemerintah (birokrasi) di dalam proses pembuatan kebijakan tentang keuangan daerah, sehingga publik dan DPRD dapat mengetahui, mengkaji, dan memberikan masukan serta mengawasi pelaksanaan kebijakan publik yang berkaitan dengan keuangan daerah atau APBD; b) efisien dimana pengelolaan keuangan daerah harus didasarkan suatu pemikiran bahwa setiap pengeluaran anggaran daerah harus diupayakan seefisien mungkin, guna menghasilkan output yang memadai. Penghematan anggaran sangat diperlukan dalam rangka mencapai efisiensi. Dengan anggaran yang ada Pemda harus mencapai target minimal. Dengan kata lain, standar pelayanan minimal merupakan target yang harus dicapai sesuai proporsi biaya yang ditetapkan; c) efektif dimana dalam proses pelaksanaan kebijakan keuangan daerah (APBD), pengelolaan anggaran haruslah tepat sasaran. Selama ini Pemda sering tidak mempedulikan apakah sasaran yang hendak dicapai dari anggaran belanja tepat atau tidak, yang penting realisasi anggaran sesuai rencana dan habis terpakai. Pemikiran seperti ini bertentangan dengan pendekatan 
anggaran kinerja yang berorientasi hasil atau output; d) akuntabilitas dimana dalam pengelolaan keuangan daerah dituntut adanya pertanggungjawaban kepada public yang dapat dilakukan secara institusional kepada DPRD. DPRD yang akan menilai apakah kinerja pemda dalam mengelola keuangan daerah atau APBD baik atau buruk dengan menggunakan kriteria atau tolok ukur sesuai apa yang direncanakan semula; e) partisipatif dimana peran serta publik secara langsung maupun tidak langsung dalam pengelolaan keuangan daerah harus dijamin. Kebijakan pembangunan dalam anggaran daerah (APBD) juga harus mengakomodasikan aspirasi publik dan mengikutsertakan masyarakat secara langsung

3. Penentuan Sektor Basis Dalam Ekonomi Regional Dengan Analisa "Location Quotient"

Mengukur suatu sektor apakah menjadi basis atau tidak, dipergunakan Location Quotient Analysis, yaitu suatu perbandingan relatif kemampuan suatu sektor dalam wilayahyang ingin di analisa. Analisa LQ akan menunjukkan tingkat keunggulan relatif kegiatan lapangan usaha di suatu wilayah dan digunakan juga untuk mengetahui kemampuan daerah dalam kegiatan sektor tertentu. Location Quotient Analysis mempunyai kelebihan dan kekurangan. Kelebihannya LQ memiliki konsep yang sederhana dan mudah diterapkan, sedangkan kekurangannya adalah penambahan unit lokasi harus disesuaikan dengan penentuan kegiatan basis dan non basis, model ini kurang bisa diandalkan jika wilayah lebih luas (Richardson, 1997).

Dalam teori basis ekonomi (economic base) dikemukakan bahwa sebuah wilayah merupakan sebuah sistem sosio-ekonomi yang terpadu. Teori inilah yang mendasari 22 pemikiran teknik Location Quotient (LQ), yaitu teknik yang membantu dalam menentukan kapasitas ekspor perekonomian daerah dan derajat keswasembadaan (Self-sufficiency) suatu sektor. Ada dua kerangka konseptual pembangunan daerah yang dipergunakan secara luas yakni konsep basis ekonomi, teori basis ekonomi beranggapan bahwa permintaan terhadap input hanya akan meningkat melalui perluasan permintaan terhadap output yang diproduksi oleh sektor basis (ekspor) dan sektor non basis (lokal) (Azis, 1994). Konsep kedua beranggapan bahwa perbedaan tingkat imbalan (rate of return) diakibatkan oleh perbedaan dalam lingkungan atau prasarana, dari pada diakibatkan adanya ketidakseimbangan rasio modaltenaga. Dalam konsep ini, daerah terbelakang bukan karena tidak beruntung atau kegagalan pasar, tetapi karena produktivitasnya rendah. Namun tak banyak studi empirik yang mempergunakan konsep kedua ini, disebabkan kelangkaan data. Data yang lazim dipergunakan dalam studi empirik adalah metode Location Quotient (LQ). 


\section{METODE}

Subyek dari penelitian ini adalah Efektifitas penyaluran alokasi dana desa yang berlokasi di Wilayah Bojonegoro dengan berfokus empat desa di kecamatan Sumberrejo kabupaten Bojonegoro dengan rentang waktu penelitian sesuai pada periode yang disesuaikan pada tahun anggaran 2019.

Perhitungan Alokasi Dana Desa berdasarkan rumus penentuan besarnya ADD yang telah ditetapkan oleh Surat Menteri Dalam Negeri No. 140/640/SJ tanggal 22 Maret 2005 secara lengkap dilampirkan pada lampiran 7. Berikut adalah rumus yang digunakan dalam penentuan besarnya ADD setiap Desa.

\section{HASIL DAN PEMBAHASAN}

1. Efektifitas Penyaluran Alokasi Dana Desa (ADD) di Kabupaten Bojonegoro

Ada beberapa proses

Penyaluran Alokasi Dana Desa (ADD) di Kabupaten Bojonegoro antara lain adalah sebagai berikut a) proses penentuan alokasi dana desa per desa dimana program pelaksanaan Alokasi Dana Desa (ADD) di Kabupaten Bojonegoro dilandasi dengan adanya Peraturan Pemerintah Nomor 47 Tahun 2015 tentang Perubahan atas Peraturan Pemerintah Nomor 43 Tahun 2014 tentang Peraturan Pelaksanaan Undang Undang Nomor 6 tahun 2014 tentang Desa (Lembaran Negara Republik Indonesia Tahun 2015 Nomor 157) dan juga Peraturan Pemerintah Nomor 22 Tahun 2015 tentang
Perubahan atas Peraturan Pemerintah Nomor 60 Tahun 2014 tentang Dana Desa Yang Bersumber Dari Anggaran Pendapatan dan Belanja Negara (Lembaran Negara Republik Indonesia Tahun 2015 Nomor 88). Untuk menentukan bagian ADD yang diterima merata (ADDM), dihitung sebesar $60 \%$ dari nilai Bagian Dana Perimbangan. Sedangkan bagian ADD yang diterima proporsional (ADDP), dihitung sebesar 40\% dari nilai Bagian Dana Perimbangan. Penentuan ADDM dan ADDP menggunakan data jumlah desa se Kabupaten Bojonegoro yang jumlahnya 419 Desa, dan jumlah Dusun (Banjar Dinas) se-Kabupaten Bojonegoro sebanyak 1.299 Banjar Dinas; b) proses penyaluran alokasi dana desa dimana proses yang akan dilakukan sehubungan dengan penyaluran ADD dimulai dengan diadakannya forum Musyawah Perencanaan Pembangunan Desa (Musrenbangdes) sebagai wadah berhimpunnya semua elemen yang ada di masyarakat, dalam menentukan Rencana Pengalokasian Dana ADD pada tahun tersebut. Musyawarah Desa ini dihadiri oleh perwakilan Kecamatan, Perangkat Desa, baik Desa Dinas maupun Desa Adat. Selain memutuskan program yang akan dilakukan, juga menentukan Petugas Penanggung Jawab Operasional Kegiatan (PJOK) dan Petugas Penanggung Jawab Administrasi Kegiatan (PJAK), serta Panitia Pelaksana Pengelolaan Alokasi Dana Desa/Kelurahan (ADD/K). Hasil dari pertemuan ini 
akan disampaikan kepada Kecamatan untuk dipergunakan sebagai pembanding laporan hasil kerja yang dilakukan setelah dana ADD diterima dan dipergunakan. Proses "Bottom Up" dalam penentuan penggunaan Alokasi Dana Desa (ADD) dimulai dari Pemerintah Desa dan Lembaga Kemasyarakatan yang menyusun Program Perencanaan dan Anggaran Penggunaan Alokasi Dana Desa (ADD) dalam tahun anggaran berjalan, melalui proses perencanaan partisipatif pada Musyawarah Perencanaan Pembangunan Desa (Musrenbangdes). Proses "Top Down" yang dilakukan oleh Pemerintah Daerah melalui Badan Pemberdayaan Masyarakat Dan Pemerintahan Desa (BPMPD), yaitu badan di bawah Pemerintah Daerah Tingkat II Kabupaten Bojonegoro yang bertugas untuk melakukan perhitungan pembagian Alokasi Dana Desa (ADD) sesuai dengan formulasi yang diberikan dalam Surat Edaran Menteri Dalam Negeri No.140/640/SJ, tanggal 22 Maret 2007 perihal "Pedoman Alokasi Dana Desa dari Pemerintah Kabupaten/Kota kepada Pemerintah Desa" sebagai acuan bagi daerah berdasarkan asas merata dan adil. Asas merata adalah besarnya bagian ADD yang sama untuk setiap desa, atau Alokasi Dana Desa Minimal (ADDM), sedangkan asas adil untuk setiap desa berdasarkan nilai bobot desa yang dihitung dengan rumus dan variable tertentu (misalnya Variabel Kemiskinan, Keterjangkauan, Pendidikan, Kesehatan, dll) atau disebut sebagai Alokasi Dana Desa Proporsional (ADDP).;

Tabel 1. Penerimaan Alokasi Dana Desa di Empat Desa, Kecamatan Sumberrejo Kabupaten Bojonegoro - Jawa Timur, Tahun 2016 - 2018

\begin{tabular}{|c|c|c|c|c|c|}
\hline \multirow{2}{*}{ No. } & \multirow{2}{*}{ Keterangan } & \multicolumn{4}{|c|}{ Desa Penelitian } \\
\hline & & \multirow[t]{2}{*}{ JATIGEDE } & KARANGDOWO & MARGOAGUNG & MEJUWET \\
\hline & & & & & \\
\hline 1 & Pembagian Merata $(60 \%)$ ADDM & $287.551 .320,00$ & $270.724 .620,00$ & $263.849 .940,00$ & $270.643 .440,00$ \\
\hline & Pembagian Proporsional (40\%) ADDP & $191.700 .880,00$ & $180.483 .080,00$ & $175.899 .960,00$ & \\
\hline 3 & Jumlah Total ADD & $479.252 .200,00$ & $451.207 .700,00$ & $439.749 .900,00$ & $451.072 .400,00$ \\
\hline 4 & Bagi Hasil Pajak/Retribusi & $21.947 .900,00$ & $23.216 .500,00$ & $45.699 .000,00$ & $21.360 .500,00$ \\
\hline & Total Dana Yang Diterima Desa & $501.200 .100,00$ & $474.424 .200,00$ & $485.448 .900,00$ & $472.432 .900,00$ \\
\hline & Pembagian Dana ADD untuk Pem Des $(70 \%)$ & $350.840 .070,00$ & $332.096 .940,00$ & $339.814 .230,00$ & $330.703 .030,00$ \\
\hline 7 & Pembagian Dana ADD untuk Operasional Desa (30\%) & $150.360 .030,00$ & $142.327 .260,00$ & $145.634 .670,00$ & $141.729 .870,00$ \\
\hline 8 & Pembagian Dana ADD untuk BPD ( $22 \%$ dari OD) & $33.079 .206,60$ & $31.311 .997,20$ & $32.039 .627,40$ & $31.180 .571,40$ \\
\hline 9 & Total ADD Se Kabupaten Bojonegoro & $287.551 .320,00$ & $270.724 .620,00$ & $263.849 .940,00$ & $270.643 .440,00$ \\
\hline & Total Bagi Hasil Pajak/Retribusi Se Kab. BJN & $191.700 .880,00$ & $180.483 .080,00$ & $175.899 .960,00$ & $180.428 .960,00$ \\
\hline 11 & Total Pembagian Dana ADD untuk BPD & $479.252 .200,00$ & $451.207 .700,00$ & $439.749 .900,00$ & $451.072 .400,00$ \\
\hline \\
\hline 1 & Pembagian Merata $(60 \%)$ ADDM & $250.258 .800,00$ & $270.724 .620,00$ & $227.276 .400,00$ & $226.563 .000,00$ \\
\hline 2 & Pembagian Proporsional ( $40 \%$ ) ADDP & $166.839 .200,00$ & $180.483 .080,00$ & $151.517 .600,00$ & $151.042 .000,00$ \\
\hline & Jumlah Total ADD & $417.098 .000,00$ & $451.207 .700,00$ & $378.794 .000,00$ & $377.605 .000,00$ \\
\hline 4 & Bagi Hasil Pajak/Re & $11.656 .100,00$ & $23.216 .500,00$ & $26.884 .300,00$ & $25.535 .700,00$ \\
\hline 5 & Total Dana Yang Diterima Desa & $428.754 .100,00$ & $474.424 .200,00$ & $405.678 .300,00$ & $403.140 .700,00$ \\
\hline 6 & Pembagian Dana ADD untuk Pem Des (70\%) & $300.127 .870,00$ & $332.096 .940,00$ & $283.974 .810,00$ & $282.198 .490,00$ \\
\hline & Pembagian Dana ADD untuk Operasional Desa (30\%) & $128.626 .230,00$ & $142.327 .260,00$ & $121.703 .490,00$ & $120.942 .210,00$ \\
\hline & Pembagian Dana ADD untuk BPD ( $22 \%$ dari OD) & $28.297 .770,60$ & $.997,20$ & $774.767,80$ & $26.607 .286,20$ \\
\hline 9 & Total ADD Se Kabupaten Bojonegoro & $250.258 .800,00$ & $270.724 .620,00$ & $227.276 .400,00$ & $226.563 .000,00$ \\
\hline & Total Bagi Hasil Pajak/Retribusi Se Kab. BIN & $166.839 .200,00$ & $180.483 .080,00$ & $151.517 .600,00$ & $151.042 .000,00$ \\
\hline 11 & Total Pembagian Dana ADD untuk BPD & $417.098 .000,00$ & $451.207 .700,00$ & $378.794 .000,00$ & $377.605 .000,00$ \\
\hline \multicolumn{6}{|c|}{ Tahun 2016} \\
\hline 1 & Pembagian Mera & $322.039 .860,00$ & $261.274 .620,00$ & $308.905 .860,00$ & $297.151 .614,00$ \\
\hline & Pembagian Proporsional (40\%) ADDP & $214.693 .240,00$ & $174.183 .080,00$ & $205.937 .240,00$ & $198.101 .076,00$ \\
\hline 3 & Jumlah Total ADD & $536.733 .100,00$ & $435.457 .700,00$ & $514.843 .100,00$ & $495.252 .690,00$ \\
\hline 4 & Bagi Hasil Pajak/Re & $8.450 .500,00$ & $23.216 .500,00$ & $22.027 .100,00$ & $25.564 .900,00$ \\
\hline 5 & Total Dana Yang Diterim & $545.183 .600,00$ & $458.674 .200,00$ & $536.870 .200,00$ & $520.817 .590,00$ \\
\hline 6 & Pembagian Dana ADD untuk Pem Des $(70 \%)$ & $381.628 .520,00$ & $321.071 .940,00$ & $375.809 .140,00$ & $364.572 .313,00$ \\
\hline & Pembagian Dana ADD untuk Operasional Desa $(30 \%)$ & $163.555 .080,00$ & $137.602 .260,00$ & $161.061 .060,00$ & $156.245 .277,00$ \\
\hline 8 & Pembagian Dana ADD untuk BPD ( $22 \%$ dari OD) & $35.982 .117,60$ & $30.272 .497,20$ & $35.433 .433,20$ & $34.373 .960,94$ \\
\hline 9 & Total ADD Se Kabupaten Bojonegoro & $322.039 .860,00$ & $261.274 .620,00$ & $308.905 .860,00$ & $297.151 .614,00$ \\
\hline & Total Bagi Hasil Pajak/Retribusi Se Kab. BJN & $214.693 .240,00$ & $174.183 .080,00$ & $205.937 .240,00$ & $198.101 .076,00$ \\
\hline 11 & Total Pembagian Dana ADD untuk BPD & $536.733 .100,00$ & $435.457 .700,00$ & $514.843 .100,00$ & $495.252 .690,00$ \\
\hline
\end{tabular}

Sumber: Olah Data BPS 
c) proses penggunaan Alokasi Dana Desa dimana penggunaan dana Alokasi Dana Desa (ADD) akan dialokasikan untuk kegiatan pemberdayaan masyarakat sebesar $70 \%$, sedangkan yang dipergunakan untuk operasional pemerintahan desa adalah 30\%. Untuk pembiayaan Badan Perwakilan Desa (BPD) dana yang dialokasikan nilainya sebesar $22 \%$ dari nilai dana operasional pemerintahan desa. Untuk menilai apakah pengalokasian Alokasi Dana Desa (ADD) berhasil atau tidak, digunakan beberapa indikator, yaitu berkurangnya jumlah penduduk miskin dan meningkatnya aktivitas mereka dalam kegiatan ekonomi, berkurangnya pengangguran karena tumbuhnya lapangan kerja di pedesaan, meningkatnya pelayanan masyarakat dan berfungsinya lembaga kemasyarakatan sebagai mitra kerja pemerintahan desa, terbentuknya Badan Usaha Milik Desa (BUMDesa) dan meningkatnya Pendapatan Asli Desa (PAD), angka kesakitan/kematian DBD/malaria/GE dan berfungsinya posyandu dan Polindes/Poskesdes di semua desa, tingkat kematian ibu, tingkat kematian bayi/anak, angka gizi buruk, terbentuknya lembaga pendidikan di luar sekolah dan meningkatnya prestasi siswa, meningkatnya peran serta masyarakat dalam system keamanan lingkungan, terciptanya pemerataan pembangunan dan berkembangnya lingkungan terpencil, terbangun dan terpeliharanya infrastruktur dan sarana/prasarana umum di pedesaan, semaraknya peranan perempuan dalam pembangunan melalui aktifitas kegiatan ekonomi produktif, meningkatnya swadaya gotongroyong dan terlaksananya bulan bhakti gotong royong masyarakat, berkembangnya teknologi tepat guna di pedesaaan dan meningkatnya upaya pelestarian lingkungan hidup. Pembagian penggunaan dana ADD di desa Margoagung tahun 2016-2018 dibagi menjadi dua aspek yaitu aspek pertama tentang pembiayaan yang dapat menggerakkan ekonomi desa, tahun pertama sebesar 68\%, tahun kedua sebesar 59\%, dan tahun ke tiga sebesar 55\% dari dana ADD yang sudah dianggarkan sebesar 70\% untuk dana pembangunan desa, serta aspek kedua tentang pembiayaan operasional yang kurang menggerakkan ekonomi desa, pada tahun pertama sebesar 32\%, tahun kedua sebesar $41 \%$, dan pada tahun ke 3 sebesar $45 \%$ yang diperoleh dari dana pembangunan desa.; d) Alokasi Dana Desa (ADD) Kabupaten Bojonegoro dan Permasalahannya dimana sesuai dengan Surat Edaran Menteri Dalam Negeri No.140/640/SJ Tanggal 22 Maret 2007 perihal "Pedoman Alokasi Dana Desa dari Pemerintah Kabupaten/Kota kepada Pemerintah Desa". Dengan adanya aliran ADD pembangunan untuk membangkitkan ekonomi desa dan sumber daya manusia dapat berjalan. Pemanfaatan ADD sudah diatur dalam Peraturan Bupati masingmasing Kabupaten, dimana 70\% dari total ADD yang diterima oleh daerah harus dimanfaatkan untuk 
pemberdayaan masyarakat desa, sementara 30\% dari ADD untuk operasional Badan Perwakilan Desa (BPD), serta di kantor desa dan perangkat desa termasuk sekretariat Kelian Banjar Dinas. Dari jumlah dana $30 \%$ untuk operasional, 25\% bagiannya untuk operasional BPD dan $75 \%$ bagiannya untuk operasional di perbekelan dan banjar dinas. Sehingga pembangunan Desa dan pemberdayaan masyarakat harus sinergis dengan penanggulangan kemiskinan.

\section{Penentuan Sektor Basis Kabupaten Bojonegoro}

Dari perhitungan terhadap Produk Domestik Regional Bruto
(PDRB) atas dasar harga konstan 2000 menurut lapangan usaha tahun 2014-2018 dari 28 kecamatan yang ada di Kabupaten Bojonegoro. Dengan menggunakan rumus di LQ (Location Quotient), diperoleh hasil indeks LQ sebagaimana yang tercantum pada Analisis LQ menunjukkan bahwa Kabupaten Bojonegoro memiliki satu nilai LQ yang menjadi unggulan dari beberapa sektor lapangan usaha. Selain itu terdapat sektor-sektor yang bukan merupakan unggulan. Adapun sektorsektor lapangan usaha yang dimiliki oleh Kabupaten Bojonegoro dapat dilihat pada tabel 2 .

Tabel 2. Hasil Perhitungan Indeks Location Quotient Kabupaten Bojonegoro

\begin{tabular}{|c|c|c|c|c|c|c|}
\hline \multirow{2}{*}{ No } & \multirow{2}{*}{ Lapangan Usaha } & \multicolumn{5}{|c|}{ Kabupaten Bojonegoro } \\
\hline & & 2014 & 2015 & 2016 & 2017 & 2018 \\
\hline 1 & Pertanian, Kehutanan, dan Perikanan & 1.220759615 & 1.42993 & 1.383241961 & 1.277786 & 1.240589 \\
\hline 2 & Pertambangan dan Penggalian & 10.06820438 & 8.34633 & 8.138307303 & 8.713266 & 9.473601 \\
\hline 3 & Industri Pengolahan & 0.198170693 & 0.223283 & 0.215306112 & 0.204824 & 0.195253 \\
\hline 4 & Pengadaan Listrik dan Gas & 0.066324762 & 0.079798 & 0.078630324 & 0.079742 & 0.080993 \\
\hline 5 & $\begin{array}{l}\text { Pengadaan Air, Pengelolaan Sampah, } \\
\text { Limbah dan Daur Ulang }\end{array}$ & 0.348567961 & 0.387415 & 0.366089027 & 0.331388 & 0.310796 \\
\hline 6 & Konstruksi & 0.778441958 & 0.881282 & 0.847545815 & 0.788219 & 0.741035 \\
\hline 7 & $\begin{array}{l}\text { Perdagangan Besar dan Eceran, } \\
\text { Reparasi Mobil dan Sepeda Motor }\end{array}$ & 0.434619952 & 0.496847 & 0.487271801 & 0.461041 & 0.448261 \\
\hline 8 & Transportasi dan Pergudangan & 0.296230639 & 0.355268 & 0.357786486 & 0.3486 & 0.350716 \\
\hline 9 & $\begin{array}{l}\text { Penyediaan Akomodasi dan Makan } \\
\text { Minum }\end{array}$ & 0.157969268 & 0.183578 & 0.180817928 & 0.169864 & 0.165126 \\
\hline 10 & Informasi dan Komunikasi & 0.920409255 & 1.052624 & 1.032856638 & 0.976494 & 0.935295 \\
\hline 11 & Jasa Keuangan dan Asuransi & 0.509204214 & 0.591456 & 0.574900977 & 0.553606 & 0.535815 \\
\hline 12 & Real Estate & 0.630851019 & 0.709191 & 0.68055999 & 0.657123 & 0.637306 \\
\hline 13 & Jasa Perusahaan & 0.168693076 & 0.19383 & 0.190249783 & 0.18126 & 0.177691 \\
\hline 14 & $\begin{array}{l}\text { Administrasi Pemerintahan, Pertahanan } \\
\text { dan Jaminan Sosial Wajib }\end{array}$ & 1.716341829 & 1.975017 & 1.910274847 & 1.801608 & 1.766591 \\
\hline 15 & Jasa Pendidikan & 0.400110684 & 0.45282 & 0.427080508 & 0.402692 & 0.381545 \\
\hline 16 & Jasa Kesehatan dan Kegiatan Sosial & 0.615736585 & 0.688298 & 0.626887381 & 0.580918 & 0.535381 \\
\hline 17 & Jasa Lainnya & 0.564713406 & 0.656525 & 0.61721855 & 0.564281 & 0.54455 \\
\hline
\end{tabular}

Sumber: Olah Data PDRB Kabupaten Bojonegoro dari BPS Kabupaten Bojonegoro, Jawa Timur Tahun 2014-2018 
Dari tabel 2 tentang hasil perhitungan analisis Location Quotient di Kabupaten Bojonegoro dapat dilihat bahwa sektor lapangan usaha yang paling unggul adalah sektor pertambangan dan penggalian tetapi dalam setiap kecamatan yang ada di Kabupaten bojonegoro memiliki sektor usaha yang menjadi unggulan, maka kebijakan pembangunan dan pengembangan sektoral perekonomian di daerah hendaknya lebih memprioritaskan sektor unggulan yang dimiliki oleh masing-masing kecamatan. Meskipun demikian, sektor lainnya tetap mendapat perhatian secara proporsional sesuai dengan potensi dan peluang pengembangannya. Pengembangan sektor unggulan hendaknya diarahkan pada upaya untuk menciptakan keterkaitan antar daerah-daetah yang ada di Kabupaten Bojonegoro. Salah satu upaya yang dapat ditempuh adalah melalui penciptaan spesialisasi yang memungkinkan bergeraknya perekonomian secara bersama-sama melalui proses pertukaran komoditas. Selain itu, masih dibutuhkan analisis lanjut untuk mengukur tingkat spesialisasi antar kecamatan di Kabupaten Bojonegoro.

\section{Kesenjangan \\ (Disparitas)}

\section{Pembangunan Ekonomi Antar} Wilayah

Perbandingkan

tingkat pertumbuhan wilayah pada kabupaten Bojonegoro adalah antar wilayah Desa, karena yang akan diamati adalah tingkat disparitas pembangunan antar desa pada tahun sebelum ada program Alokasi Dana Desa, pada saat telah diterapkannya program Alokasi Dana Desa.

Tabel 3. Produk Domestik Regional Bruto (PDRB) di Kabupaten Bojonegoro Atas Dasar Harga Konstan 2000, Tanpa Migas 2014-2018

\begin{tabular}{|c|c|}
\hline \multicolumn{2}{|c|}{ PDRB Di Bojonegoro } \\
\hline Tahun & PDRB \\
\hline 2014 & Rp 26,155,075.67 \\
\hline 2015 & Rp 28,768,896.63 \\
\hline 2016 & Rp 31,654,949.27 \\
\hline 2017 & $\operatorname{Rp} 34,324,655.23$ \\
\hline 2018 & Rp 37,154,007.12 \\
\hline
\end{tabular}

Sumber: BPS Kabupaten Bojonegoro Jawa Timur 2019

Produk Domestik Regional Bruto (PDRB) di Kabupaten Bojonegoro diatas dapat diketahui bahawa dengan mengukur adanya ketimpangan atau disparitas antar desa diharapkan dapat diketahui bahwa jika perlakuan yang diberikan oleh pemerintah daerah Kabupaten Bojonegoro dalam hal pemberian Alokasi Dana Desa kepada keempat Desa, yaitu Desa jatigede, Desa karangdowo, Desa Margoagung dan Desa Mejuet sama, maka seharusnya tingkat disparitas pembagunan Desa relatif kecil. Akan tetapi karena data PDRB yang dibutuhkan tidak ada di BPS, maka sulit untuk mendapatkan PDRB setingkat Desa. Yang paling rendah hanya sampai tingkat Kabupaten. 
Tabel 4. Jumlah Penduduk di Kabupaten Bojonegoro 2014-2018

\begin{tabular}{|c|c|}
\hline \multicolumn{2}{|c|}{ Data Penduduk di kab. Bojonegoro } \\
\hline Tahun & Jumlah Penduduk \\
\hline 2014 & 2858626 \\
\hline 2015 & 280916 \\
\hline 2016 & 2902378 \\
\hline 2017 & 2905086 \\
\hline 2018 & 2499156 \\
\hline
\end{tabular}

Sumber: BPS Kabupaten Bojonegoro Jawa Timur 2019

Dengan menggunakan formulasi Indeks Williamson, data dari Tabel 3 dan Tabel 4 dapat dimasukkan ke dalam formula tersebut. Hasil dari perhitungan tersebut merupakan Indeks Williamson Kabupaten Bojonegoro dari 2014-2018, yang dirangkum dalam Tabel 4.8.

Tabel 5. Indeks Williamson Kabupaten Karangasem Tahun 2014-2018

\begin{tabular}{|c|c|}
\hline Tahun & Indeks \\
\hline 2014 & 0,91 \\
\hline 2015 & 0,69 \\
\hline 2016 & 0,66 \\
\hline 2017 & 0,59 \\
\hline 2018 & 0,61 \\
\hline Rata-Rata (Iw) & 0,69 \\
\hline
\end{tabular}

Sumber: Olah data PDRB dari BPS Kabupaten Bojonegoro Jawa Timur 2014-2018

Indeks Williamson meneliti hubungan antara disparitas regional dengan tingkat pembangunan ekonomi. Ditemukan bahwa selama tahap awal pembangunan, disparitas regional menjadi lebih besar dan pembangunan terkonsentrasi di daerah-daerah tertentu. Pada tahap yang lebih "matang", dilihat dari pertumbuhan ekonomi, tampak adanya keseimbangan antar daerah dan disparitas berkurang secara signifikan.

Indeks Williamson dapat digunakan untuk melihat ketimpangan atau disparitas antar wilayah yang dihitung. Jika nilai Iw mendekati angka 1 berarti terjadi disparitas yang tinggi (sangat timpang) pada wilayah tersebut, sedangkan jika nilai Iw mendekati 0 berarti pembangunan yang terjadi pada wilayah tersebut sangat merata (tidak timpang).

Tabel 6. Grafik Indeks Williamson

Kabupaten Bojonegoro Tahun 20142018

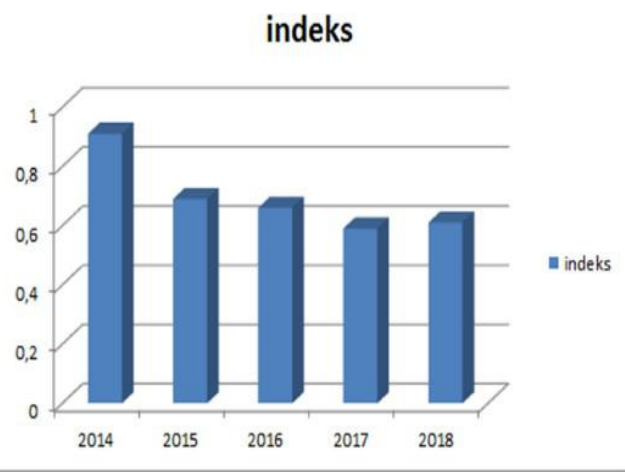

Sumber: Olah data BPS

Dari hasil perhitungan nilai Indeks Williamson yang dintunjukkan pada gambar 4.2 tentang Grafik Indeks Williamson Kabupaten Bojonegoro Tahun 2014-2018 diatas dipat diketahui bahwa gambar tersebut menunjukkan selama lima tahun nilai indeks-nya mengalami penurunan yaitu pada tahun pertama nilai indeks-nya 0,91 , tahun kedua 0,69 tahun ketiga 0,66, tahun keempat 0,59 , dan pada tahun kelima nilai indeks-nya mengalami kenaikan 
yaitu 0,61 . Nilai yang diperoleh dari perhitungan mendekati nilai 1 sehingga dapat dikatakan terjadi ketimpangan (disparitas) pembangunan antar kecamatan dalam Kabupaten Bojonegoro tetapi cenderung menurun angka indeksnya dari tahun ke tahun.

Disparitas pendapatan antar daerah merupakan topik yang perlu analisa ulang, karena disparitas merupakan suatu hal yang dapat menghambat pembangunan daerah khususnya dan pembangunan nasional pada umumnya. Dari Indeks Williamson dapat dilihat bahwa terjadi proses disparitas atau kesenjangan yang terjadi disetiap tahunnya, sesuai dengan teori kurva ketimpangan pembangunan antar wilayah yang berbentuk " $U$ " terbalik (reserve U-shaped curve). Pada permulaan proses pembangunan suatu wilayah, dalam hal ini ketimpangan pembangunan antar wilayah di Kabupaten Bojonegoro cenderung meningkat. Proses ini akan terjadi sampai ketimpangan tersebut mencapai titik puncak. Setelah itu, apabila proses pembangunan terus berlanjut, maka secara perlahan ketimpangan pembangunan antar wilayah tersebut akan menurun. Perhitungan dari tahun 2014 hingga 2018 diperoleh angka-angka sebagai berikut : Iw2014 = 0.91, $\quad$ Iw2015 = 0,69, Iw2006 = 0,66, Iw2017 = 0.59, $\operatorname{Iw} 2018=0.61$.

Faktor-faktor utama yang menjadi penyebab atau pemicu terjadinya ketimpangan pembangunan antar Desa yang ada di kecamatan Sumberejo Kabupaten Bojonegoro, diantaranya dikarenakan a) adanya perbedaan kondisi demografis yang cukup besar antar daerah, yang meliputi perbedaan tingkat pertumbuhan dan struktur kependudukan, perbedaan tingkat pendidikan dan kesehatan, perbedaan kondisi ketenagakerjaan dan perbedaan dalam tingkah laku dan kebiasaan, serta etos kerja yang dimiliki masyarakat daerah bersangkutan. Perbedaan kondisi demografis tersebut dapat mempengaruhi produktivitas kerja masyarakat pada daerah bersangkutan; b) adanya perbedaan yang sangat besar dalam kandungan sumberdaya alam pada masingmasing desa. Perbedaan kandungan sumberdaya alam dan tingkat kesuburan lahan akan mempengaruhi upaya-upaya untuk mendorong pembangunan pertanian pada masing-masing daerah, diantara empat desa yang diteliti; c) pembangunan daerah melalui peningkatan penyediaan lapangan kerja dan tingkat pendapatan masyarakat. Demikian pula sebaliknya bilamana, konsentrasi kegiatan ekonomi pada suatu daerah relatif rendah yang selanjutnya juga mendorong terjadi pengangguran dan rendahnya tingkat pendapatan masyarakat setempat; d) terkonsentrasinya kegiatan ekonomi yang cukup tinggi pada wilayah tertentu jelas akan mempengaruhi ketimpangan pembangunan antar wilayah. Pertumbuhan ekonomi 
daerah akan cenderung lebih cepat pada daerah dimana terdapat konsentrasi kegiatan ekonomi yang cukup besar. Kondisi tersebut selanjutnya akan mendorong proses Investasi merupakan salah satu yang sangat menentukan pertumbuhan ekonomi suatu daerah. Jika sistem pemerintahan yang dianut adalah otonomi atau federal, maka dana pemerintah akan lebih banyak dialokasikan ke daerah sehingga ketimpangan pembangunan antar wilayah akan cenderung lebih rendah. Investasi swasta perlu ditarik, tetapi swasta baru akan mau menginvestasikan dananya jika iklim usaha di daerah tersebut kondusif; e) adanya keseriusan upaya pemerintah pusat maupun daerah dalam rangka penanggulangan ketimpangan pembangunan antar daerah dalam suatu negara atau wilayah. Pemerintah perlu fokus di satu hal kekuatan dari masing masing Desa, agar dapat terjadi penguasaan bidang tersebut dengan dukungan dari pemerintah pusat atau daerah; f) pelaksanaan otonomi desa dan desentralisasi pembangunan desa juga dapat digunakan untuk mengurangi tingkat ketimpangan pembangunan antar wilayah. Karena dengan adanya otonomi desa dan desentralisasi pembangunan, maka aktifitas pembangunan daerah, termasuk daerah terbelakang akan dapat lebih digerakkan karena ada wewenang yang berada pada pemerintah daerah dan masyarakat setempat. Pemanfaatan ADD dalam hal ini sangat membantu mempercepat turunnya disparitas tersebut, tentunya dengan pemanfaatan dana yang tepat sasaran. Dengan melakukan pembenahan terhadap keenam faktor yang ada, diharapkan disparitas pembangunan antar wilayah dapat dikurangi sehingga menjadi merata pembangunannya.

\section{Analisis Klassen Typology Kecamatan Di Kabupaten Bojonegoro Jawa Timur}

Pada analisa tipologi klassen, data yang dibutuhkan adalah data BPS tentang laju pertumbuhan PDRB untuk tiap kecamatan dalam Kabupaten Bojonegoro - Provinsi jawa Timur dalam kurun waktu tahun 2014-2018. Lebih lanjut, untuk menilai laju pertumbuhan terhadap masing-masing kecamatan dapat digolongkan menjadi 4 kuadran yaitu kuadran 1 jika cepat maju dan cepat tumbuh, kuadran 2 jika berkembang cepat, kuadran 3 jika maju tetapi tertekan, serta kuadran 4 jika relative tertinggal. Hasil dari pengelompokkan data-data tersebut kemudian dimasukkan ke dalam kuadran yang menunjukkan apakah ke 28 Kecamatan yang berada di Kabupaten Bojonegoro masuk ke dalam kuadran 1 cepat maju dan cepat tumbuh, atau kuadran 2 berkembang cepat, atau kuadran 3 maju tetapi tertekan, atau kuadran 4 relative tertinggal.

Dari analisa tipologi klasson menunjukkan bahwa adanya perbedaan PDRB dan laju pertumbuhan diantara empat desa yang diteliti. Berdasarkan uraian 
tersebut, maka dapat diambil kesimpulan bahwa program Alokasi Dana Desa yang sudah dilaksanakan selama tiga tahun yaitu dari tahun 2017 hingga tahun 2019 belum memberikan dampak positif, yang tergambar dalam besarnya Indeks Williamson yang masih tinggi walaupun mengalami penurunan dari tahun ke tahun tetapi besarnya indeks tetap mendekati angka 1 yang berarti cenderung mengalami kesenjangan antar wilayah Kecamatan di Kabupaten Bojonegoro.

\section{E. SIMPULAN DAN SARAN}

Dari analisa yang telah dilakukan pada empat desa di Kecamatan Sumberejo Kabupaten Bojonegoro, Jawa Timur Anatara lain adalah a) penyaluran Alokasi Dana Desa di empat desa tersebut belum mencapai efektifitas yang optimal. Hal tersebut dapat dilihat dari masih adanya kesenjangan (disparitas) pembangunan ekonomi antar wilayah kecamatan dan cenderung memiliki nilai Indeks Williamson dari tahun 2014 hingga tahun 2018 mendekati nilai 1 (satu); b) melalui analisa Klassn Typology dapat diketahui bahwa hasil dari pembangunan ekonomi selama tahun 2014 hingga tahun 2018, dari 28 kecamatan di Kabupaten Bojonegoro, Jawa Timur hanya beberapa daerah yang termasuk dalam kategori daerah cepat maju dan cepat tumbuh. Alokasi Dana Desa yang diharapkan sebagai penggerak ekonomi Desa yang mendukung ekonomi Kecamatan masih belum dapat mengangkat ke 28 kecamatan tersebut menuju daerah cepat maju dan cepat tumbuh.

\section{DAFTAR PUSTAKA}

Abdullah, F. (1998). Merubah Kebijakan Publik. Pustaka Pelajar. Yogyakarta. Abimanyu, A. \& Megantara, A. (2009). Era Baru Kebijakan Fiskal-Pemikiran, Konsep, dan Implementasi. Penerbitan Buku Kompas. Jakarta.

Adisasmita, Rahardjo H. (2005). Dasar-Dasar Ekonomi Wilayah. Penerbit Graha Ilmu.Yogyakarta.

Apgar, W.C. \& Brown, H.J. (1987). Microeconomic and Public Policy. Scot, Foresman and Company. United States of America. Arief, S. (1993). Metodologi Penelitian Ekonomi. Penerbit Universitas Indonesia - UI Press. Jakarta Arifin, B. \& Rachbini, D.J. (2001). Ekonomi Politik dan Kebijakan Publik. PT Gramedia Widiasarana Indonesia. Jakarta.

Atmadja, A.P.S. (1996). Kapita Selekta Keuangan Negara - Suatu Tinjauan Yuridis. Universitas Tarumanegara. Jakarta.

BPS. 2019. Jawa Timur Dalam Angka. Penerbit BPS. Jawa Timur

BPS. 2019. Bojonegoro Dalam Angka.

Penerbit BPS. Bojonegoro Jawa Timur

BPS. 2018. Bojonegoro Dalam Angka.

Penerbit BPS. Bojonegoro Jawa Timur

BPS. 2017. Bojonegoro Dalam Angka. Penerbit BPS. Bojonegoro Jawa Timur

BPS. 2016. Bojonegoro Dalam Angka. Penerbit BPS. Bojonegoro Jawa Timur 
Vol.1 No.2 Desember 2019

BPS. 2015. Bojonegoro Dalam Angka.

Penerbit BPS. Bojonegoro Jawa Timur

Bungin, B. (2007). Penelitian Kualitatif - Komunikasi, Ekonomi, Kebijakan Publik, dan Ilmu Sosial Lainnya. Penerbit Kencana. Jakarta.

Djadijono, M. (2006). Membangun Indonesia Dari Daerah. Centre for Strategic and International Studies (CSIS). Jakarta.

EW Abryandoko (2019). Studi Penerepan Value Stream Mapping untuk Mengurangi Pemborosan pada Proses Suplay Chain (Studi Kasus di Home Industry Batu Bata Merah di Desa Ledok Kulon Kabupaten Bojonegoro).

Penerbit IENACO (Industrial Engineering National

Conference) 72019 